\title{
The Advocate's Dilemma: Framing Migrant Rights in National Settings
}

\author{
MARIA LORENA COOK \\ Department of International and Comparative Labor, School of Industrial and Labor Relations, \\ Cornell University
}

\begin{abstract}
This article identifies and explores the dilemma of migrant advocacy in advanced industrial democracies, focusing specifically on the contemporary United States. On the one hand, universal norms such as human rights, which are theoretically well suited to advancing migrants' claims, may have little resonance within national settings. On the other hand, the debates around which immigration arguments typically turn, and the terrain on which advocates must fight, derive their values and assumptions from a nation-state framework that is self-limiting. The article analyzes the limits of human rights arguments, discusses the pitfalls of engaging in national policy debates, and details the challenges for advocates of advancing the cause of policy reform and shifting the frame for thinking about migration over the long term.
\end{abstract}

\section{Introduction $^{1}$}

Human migration today is a core feature of globalization. Yet perhaps more than any other phenomenon, it also underscores the conflict and tensions between sovereignty of the nation-state and the cross-border flows characteristic of a global economy. People cross borders to escape violence and persecution, but they also move toward work, education, family, and better economic opportunities. Global communications technologies-television, movies, the internet, and cell phones-facilitate the transmission of information about migration destinations and help maintain transnational social networks. Richer nations with growing economies and aging populations increasingly rely on migrants to do the "dirty, dangerous, and difficult" jobs (ILO, 2002).

At the same time, most nations have moved toward an increasingly restrictive set of immigration policies. Immigration policy has become conjoined with national and regional (in the case of the EU) security, taking its place alongside efforts to combat drug trafficking and terrorism. The securitization of immigration has bolstered national governments' efforts to reinforce and redefine their borders just as globalization is expanding (Andreas, 2009). Rather than constrain nation-states' efforts to control their border and immigration policies (Hollifield, 2004; Sassen,

Correspondence Address: Maria Lorena Cook, Department of International and Comparative Labor, School of Industrial and Labor Relations, Cornell University, Ithaca, NY 14853-3901, USA. Email: MLC13@cornell.edu 
1999), globalization has rendered borders even more salient as barriers to the ingress and movement of non-citizens (Andreas, 2003; Guiraudon \& Lahav, 2000).

In this context, the question of how to counter or reverse restrictive national policies toward migrants becomes especially difficult for migrant advocates and for migrants themselves. One approach is to draw on international human rights law and principles to underscore the notion that migrants have rights that states are obligated to uphold. Framing the treatment of migrants as a human rights issue has several advantages: 1) most countries have signed on to the main conventions on human rights; ${ }^{2}$ 2) a human rights frame supposes equal entitlement and thus equal treatment and access to basic rights protections, thereby undermining efforts to exclude migrants or to categorize non-citizens as a less deserving class of people; 3) a human rights framing implies a universalist approach, and is therefore more consistent with global migration, in which rights-bearing individuals move back and forth across national borders. International human rights law, then, would appear to be a logical structure upon which to construct an alternative justification for promoting and defending the rights of migrants within national boundaries.

But how effective are universal human rights framings of migration in persuading citizens to alter their support for restrictive border and immigration policies? There are political, legal, and discursive limits on the use of human rights frames, particularly in the United States. Moreover, much of the contemporary debate on immigration in the US and other advanced industrial democracies revolves around arguments about security, economics, and law-arguments that are rooted in the nation-state. This gives rise to the advocate's dilemma: on the one hand, universal norms such as human rights, which are theoretically well suited to advancing immigrants' claims, may have little resonance within national settings; on the other hand, the debates around which immigration arguments typically turn, and the terrain on which advocates must fight, derive their values and assumptions from a nationstate framework that is self-limiting, for reasons I explain below.

How does this dilemma play out for migrant advocates? What are the pitfalls of engaging in national policy debates? Why are human rights approaches less effective in these debates? How do advocates navigate the discursive terrain in ways that would enable them to advance the cause of policy reform and shift the frame for thinking about migration over the long term? How to overcome the advocate's dilemma?

This article considers these questions in the context of the contemporary United States. I first review debates on the effectiveness of human rights arguments for public advocacy around immigrants' rights and point out ways in which human rights frames are limited instruments. I look next at advocacy groups' use of rights frames that are based on national laws, institutions, and traditions, and indicate their limitations in campaigns for unauthorized migrants. I then identify the ways in which debates over immigration have unfolded in the United States and argue that immigrant advocates are drawn into national policy debates that are largely framed by immigration opponents. I also show how states pose additional challenges for advocates through the securitized framing of migration. I conclude with a discussion of the challenges advocates must overcome if we are to advance toward a radically different way of thinking about the place of migration in our times. 


\section{Assumptions, Definitions, and Normative Concerns}

Several clarifications about my focus and the assumptions I make in this paper are in order here. First, my primary focus is on advocacy on behalf of unauthorized migrants. Advocates face greater framing challenges in this case, as I show below. I also look at advocacy on behalf of, rather than by, unauthorized migrants. In most cases this advocacy consists of citizens or legal residents working to change policy and secure rights and protections for non-citizens, a form of claims-making that can be considered altruistic or solidary, in contrast with migrants organizing to represent themselves (Passy, 2001). I assume that the frames and strategies that each group adopts will differ (Schwenken, 2005). While migrants themselves seek ways of framing that advance particular self-perceptions and identities, for which a human rights approach might be well suited, advocacy groups are primarily externally directed and seek approaches that will be effective in influencing policy and public opinion.

Second, I use the terms "frames" and "framing" to mean a system of values and beliefs (i.e. of meaning) and the construction thereof, that resonates with members or constituents and motivates them to action (Benford \& Snow, 2000). The contentious politics surrounding immigration renders a focus on frames and framing processes especially relevant (Tarrow, 1998, pp. 106-122).

Third, I look at public advocacy rather than litigation strategies. Litigation strategies are aimed at persuading courts, whereas public advocacy tries to influence public opinion, politicians, and policymakers. Litigation strategies are not divorced from public opinion, of course, but they are constrained (and enabled) by laws and judicial interpretation. In this way, "rights arguments" may be effective in the courts, but not yet resonate in the court of public opinion.

Fourth, I assume that immigration policy largely reflects public opinion, and that vocal constituents communicate these preferences to their representatives in the U.S. Congress, where most immigration legislation is made. Here I side with those authors who identify domestic politics as the primary determinant of immigration policy in the United States (Freeman, 1995; Money, 1999), rather than international factors, such as human rights norms and international trade, acting as significant constraints on states' elaboration of immigration controls (Hollifield, 2004; Sassen, 1999; Soysal, 1994). This is not to deny that foreign policy concerns have long played a central role in constituting immigration policy. For example, Cold War influences shaped immigration policies toward Central Americans in the 1980s and continue to define the differences in policies aimed at Cuban and Haitian migrants today, and the U.S. government has stepped up its scrutiny of Muslim immigrants as part of its "war on terror" in the wake of 9/ll (Fernandes, 2007; Koulish, 2010). However, my argument is that domestic public attitudes may also influence immigration policies in ways that often contradict market and foreign policy logics. ${ }^{3}$

Finally, I take a normative position on the ultimate goal of international migrant advocacy, which is that the right to free movement should be recognized and protected. This "ideal" is clearly not practical in the foreseeable future, nor does it necessarily represent the ideal endpoint for many advocates, who may not want to jettison immigration controls. Yet in making this normative claim I am also posing the question of what it would take to move toward public acceptance of this ideal over the long term. I argue that the most commonly used discourses among 
advocates are limited precisely because they do not break with the premise that states have a "right" to exclude people from their territories. I recognize that advocates will have more pragmatic goals that, if achieved, can improve the situation of unauthorized migrants significantly. However, my point is that anything short of free movement will eventually reproduce the exclusions that diminish human dignity.

There is considerable discussion among political theorists about how to construct a morally defensible position on immigration and whether the exclusions of immigration policies are consistent with liberalism (Carens, 1987; P. Cole, 2000; Walzer, 1983). Similarly, theorists have shown how concepts of nation and national belonging must be rethought or even purged to begin to construct a philosophy of movement (Sharma, 2006; Stevens, 2009). These discussions are essential, but widespread acceptance (even by theorists) of the "need" for national borders illustrates how far we have to go in crafting an alternative vision (P. Cole, 2000). My aim here is more limited: it is to highlight the tensions between advocacy discourses and this goal of free movement, and to identify the counter-framing challenges that pro-migrant advocates face.

\section{Promise and Limits of International Human Rights}

Migrants, whether or not they are authorized by states that they enter, are entitled to recognition and protection of their basic human rights as stated in numerous international human rights documents and conventions. ${ }^{4}$ These principles, laws, and conventions enable migrant advocates to construct a universal or "global frame" for migrant rights that essentially renders borders and national immigration laws immaterial to the goal of upholding the fundamental rights of migrants as human beings and as migrants. In this way the human rights frame cuts through the nationally bounded frameworks within which most public discourse about migrants takes place.

Many scholars and advocates see in international human rights frameworks the means through which to secure and protect rights for non-citizens who may otherwise find themselves excluded or adversely affected by national laws. Despite his acknowledgment of significant impediments to the effective use of human rights arguments, David Cole (2006) states that human rights discourse "offers tremendous normative power and potential for advancing social justice on behalf of foreign nationals in the United States” (p. 629). Beth Lyon (2008) shows how immigrant worker advocates in the US have begun to appeal to international law forums to seek favourable judgments and to broaden awareness of the conditions immigrant workers face. She states that "the language of international human rights can be unifying and meaningful” for immigrants.

Yet despite recognition of its potential, many scholars also agree that international human rights arguments still face considerable obstacles. In the United States, immigrant advocates rarely use international human rights arguments in their domestic work or in the courts (Lyon, 2008, p. 40). This is due in part to scepticism about human rights and to constraints on the Courts' interpretation of the constitutionality of immigration laws (D. Cole, 2006, p. 629). ${ }^{5}$ In the international arena, states generally remain impervious to human rights violation charges, especially in the area of unauthorized migration. This is so for several reasons. 
International human rights law with regard to migration remains relatively weak and cedes to states' sovereign power to restrict access to their territory. Although international covenants stipulate humane treatment of persons regardless of citizenship status, they do not impose obligations on states to accept non-citizens or to provide them with access to basic rights (Dauvergne, 2005). Legal systems are also still rooted in national institutions, law, and politics, which are normally oriented around rights of citizens. As Catherine Dauvergne (2008) notes in Making People Illegal, "Human rights arguments have worked poorly for those without a legal right to be present. It has proven remarkably difficult to separate a legal right to be present within a state from a right to simply 'be'” (2008).

Advanced industrial democracies that violate rights are also less vulnerable to international pressure or condemnation than are poorer nations. No rich country has ratified the International Convention on the Rights of Migrant Workers and their Families, whereas most developing (and migrant-sending) countries have (Yau, 2005). In the realm of unauthorized migration, moreover, wealthier countries have converged in their more restrictive policies, leaving few outside of this group able to criticize them on human rights grounds.

Another difficulty with human rights discourses is that they often appear abstract, especially in the absence of effective enforcement in international forums (D. Cole, 2006, p. 632; Dauvergne, 2008). They also tend to be highly legalistic and technical (Elias, 2008, p. 296), and fail to elicit responses from mass publics in ways that could be politically effective. Social movement scholars (Benford \& Snow, 2000), cultural sociologists (Lamont \& Thevenot, 2000) and linguists (Lakoff, Hazen, \& Dean, 2004; Lakoff \& Ferguson, 2006) all note the importance of "resonance" with constituents' cultural context to enable mobilization around an issue. Despite the global advance of human rights norms, however, international human rights discourses still lack resonance in many advanced liberal democracies, especially in the United States. Finally, some scholars have noted the problematic character of "mainstream" human rights discourses because they tend to ignore inequalities in access to rights that derive from economics and power relations, which have gendered implications, among other consequences (Basok, 2009; Elias, 2008, p. 285).

These reservations about human rights discourses have led some scholars to distinguish between juridical and sociological notions of rights, in which the former represents a more traditional, legalistic view and the latter stresses the political process of identifying and claiming rights within specific social struggles rather than through law and legal institutions (Grugel \& Piper, 2007, pp. 18 \& 32; Merry, 2003). While this may be a promising way to think about the liberating possibilities of "rights talk" for migrants themselves, I argue that human rights discourses in general are less effective today in persuading publics of the rights of undocumented or irregular migrants to move or remain in a country where they lack status. Human rights discourses fall short on legalistic grounds, because of the weakness of international law protections for non-status migrants, and in generating cultural resonance with citizens, because of the emotional power of competing, national frames for viewing migration. 


\section{National Rights Frames in U.S. Immigrant Advocacy}

In his report to the Human Rights Council of the UN General Assembly, Dr. Jorge Bustamante, the Special Rapporteur for Migration, concluded that "the United States has failed to adhere to its international obligations to make the human rights of the 37.5 million migrants living in the country...a national priority, using a comprehensive and coordinated national policy based on clear international obligations" (Bustamante, 2008). The report argued that the US was violating international law and standards as found in the International Covenant on Civil and Political Rights (ICCPR), ${ }^{6}$ the Universal Declaration of Human Rights, and the Convention and the Protocol relating to the Status of Refugees. Despite the report's source and its hard-hitting criticism, it garnered only limited headlines in the United States. Although two national advocacy organizations, the American Civil Liberties Union (ACLU) and the National Network for Immigrant and Refugee Rights (NIRR), coordinated the Special Rapporteur's visit (Lyon, 2008, p. 38), most advocacy groups did not highlight the document in their campaigns. Indeed, many immigrant advocates seemed unaware of its existence.

Was this a missed opportunity, the result of inefficient dissemination by advocacy groups? Or did this omission reflect the general weakness of human rights arguments in the United States? A review of the websites of eight national immigrant advocacy organizations in the United States showed that most of these advocacy groups employed a rights-based discourse in at least some part of their public communications. ${ }^{7}$ References to human rights, however, tended to be vague and disconnected from specific international conventions. ${ }^{8}$ More often rights were defined in national-legal terms. Groups framed their advocacy in terms of workers' rights, civil rights, "legal rights," and constitutional rights. ${ }^{9}$ Civil rights were stressed by five of the eight groups reviewed, whereas legal advocacy groups, such as the American Civil Liberties Union and the National Immigration Law Center, emphasized constitutional rights.

Such national rights frames arguably resonate more in the United States than do international rights claims. For example, civil rights constitutes a powerful "master frame" for social movements in the US, since it draws upon the civil rights struggles among African Americans and other minority groups in the United States (Snow \& Benford, 1992, p. 145). Moreover, the power of national rights approaches resides in the implicit claim that immigrants are entitled to the same rights and protections as U.S. citizens, and that the violation of these rights in the case of immigrants may redound upon citizens. But civil and constitutional rights frames may not always work for noncitizens, since the law does not entitle them to equal treatment and equal protection in all cases. The extension of these rights claims to the undocumented is even more difficult. As Bosniak (2000) notes, citizenship is typically defined in opposition to alienage. In this way, frames that advance rights based on national laws are limited in that they ultimately rely on insider/outsider, citizen/alien distinctions.

This is not to say that there are no areas in which citizenship or immigration status do not matter. Some legal rights, protections, and entitlements in the US today apply equally to citizens and non-citizens, legal or otherwise. This is the case with some constitutional rights, access to public K-12 education, and labour rights to the extent that these are protected in U.S. labour law (D. Cole, 2006; Lyon, 2008). Advocacy 
groups can focus on realizing those rights to which even the undocumented are entitled by law by virtue of their presence in the territory or their status as a worker.

Nonetheless, even here legal protections for immigrants have been eroded as the enforcement climate in the US has hardened. The best example of this in the area of workers' rights is the U.S. Supreme Court's 2002 decision in the case of Hoffman Plastic Compounds v. National Labor Relations Board, in which the Court determined that workers' undocumented immigration status precluded them from receiving back pay as a remedy in cases of violations of their right to engage in union activity or in cases of workplace discrimination. The argument of the majority of justices was that lending full protection to undocumented workers would encourage illegal immigration (Lyon, 2008, p. 29). Federal and state governments have passed laws in recent years that further circumscribe non-citizens' rights by limiting their access to welfare programs, employment rights, and procedural rights such as due process.

The shortcomings of rights framings for migrants have been further noted by a number of scholars, both in the United States and in other countries. Statham and Mynott (2002) show that framing issues in terms of racial politics and anti-racism resonated better in Britain than did using migrant rights frames. Fujiwara (2005) argues that humanitarian reasoning provided an effective counter-framing strategy to combat laws that made non-citizens ineligible for public benefits in Oregon, despite an initial effort to campaign under the banner of "immigrant rights are human rights.” Schwenken (2005) examines how European advocates framed migrant domestic workers' issues in terms of combating human trafficking in order to gain access to policymakers, even while migrant domestic workers themselves preferred to push the "workers' rights" frame. In each of these cases, "rights talk" did not resonate with media, officials, and the broader public as much as did other rationales, such as racism, aid to the elderly and the disabled, and domestic slavery. Rightsbased discourses, while perhaps consistent with long-term goals of advocates (and migrants), were often insufficient for achieving specific gains in real campaigns.

\section{The Evolution of U.S. Immigration Policies in the 2000s}

The history of immigration in the United States is replete with examples of restrictive policies and nativist reactions against newcomers (Nevins, 2002; Ngai, 2006). The present wave of anti-immigrant sentiment and immigration restriction emerged in California with the 1994 passage of Proposition 187, a restrictive measure that would have, among other things, required teachers and health care workers to report undocumented immigrants using their services. Although Proposition 187 did not survive a court challenge, other state and local initiatives would later multiply across the country, especially in the first decade of the new century (Moser, 2006).

At the same time that U.S., Mexican, and Canadian authorities celebrated the cross-border flow of trade and capital with the signing of the North American Free Trade Agreement, the U.S. government redoubled its efforts at boundary enforcement on the US-Mexico border (Nevins, 2002). In 1994 the U.S. Attorney General announced an enforcement initiative designed to "shut down the traditional corridors for the flow of illegal immigration along the southwest border” (U.S. GAO, 
2006, pp. 6-7). The strategy called for increasing control of the border through the addition of personnel and technology in order to make border crossings more costly and difficult. As urban areas came under control, migrants would be diverted to more remote areas where they could be detected and apprehended by Border Patrol more easily and where the difficult terrain of mountains, rivers, and deserts would act as a deterrent. The result of this initiative, called the Southwest Border Strategy, was a redirection of the migrant flow toward eastern California and the Sonora Desert in Arizona, continued crossing attempts, and an increase in border-crossing deaths due to exposure (Cornelius \& Lewis, 2007; Nevins, 2008).

In the wake of the September 11, 2001, terrorist attacks in the United States, immigration became increasingly tied to national security (Koulish, 2010; Nguyen, 2005). The reorganization of border enforcement and immigration under the Department of Homeland Security in 2003; the stepped-up enforcement at the border in the form of a greater number of Border Patrol agents, National Guard deployment, proposed construction of a 700-mile border fence, and use of virtual technology (Andreas, 2009, pp. 156-158; Koulish, 2010; U.S. GAO, 2009); vigilante initiatives such as the Minutemen; and media attention, as in CNN's Lou Dobbs' "broken borders" series (Chavez, 2008), all reinforced the notion that borders needed to be "secured."

Working through the Department of Homeland Security, the administrations of George W. Bush (2001-2009) and Barack Obama (2009-2013) concentrated on enforcing existing laws and increased the financial and human resources that made it possible for Immigration and Customs Enforcement (ICE) to expand its apprehension of immigrants slated for deportation. In 2006, ICE began a series of strategically targeted workplace raids. Several thousand immigrants were arrested, detained, and deported in these raids. Deportations increased each year: from 288,663 individuals in FY 2007 to a record 387,790 in FY 2009, a five percent increase over the FY 2008 total of 369,221 deportations (Hsu \& Aizenman, 2010; Park, 2008). Under its National Fugitive Operations Program, ICE began in 2003 to round up "criminal" and "fugitive aliens. ${ }^{10}$ This included individuals whose actions ranged from serving out a jail term for homicide or armed robbery to failure to obey a deportation order; many "non-fugitive" immigrants were also apprehended at home, at parking lots, at train and bus stations, and at traffic stops (Mendelson, Strom, \& Wishnie, 2009). Nearly 380,000 immigrants were held in administrative detention in 2009, another record (Detention Watch Network, 2010).

The scale and speed with which these enforcement measures were enacted in a relatively short period made it difficult to counter them with any large or effective campaign. Despite polls indicating that most Americans supported immigration reform (Doherty, 2007), politicians from both parties continued to resist legalization for undocumented immigrants. The U.S. Congress repeatedly failed to pass immigration reform, leaving unaddressed the question of what to do about 12 million undocumented immigrants. Immigration reform remained on the back burner well into the second year of President Obama's administration. Moreover, the Obama administration retained, and in some cases, escalated many of the enforcement initiatives begun in the Bush administration, such as the 287(g) program of collaboration between local law enforcement and immigration authorities, detention and deportation policies, and border security, including the deployment of 1,200 National Guard troops (Archibold, 2010b; Preston, 2009). 
States and municipalities continued to forge immigration-related initiatives despite the federal government's jurisdiction over immigration matters. The most contentious example to date of a state initiative on this matter was SB 1070, a bill approved by the Arizona legislature and signed into law by the Governor in April, 2010. ${ }^{11}$ Among other immigration-related measures, the bill called on law enforcement to check immigration status (Archibold, 2010a). Polls taken shortly after the passage of Arizona's controversial immigration law showed that a majority of Americans supported it (Pew Research Center, 2010). Within months of the law's passage, at least twenty states were preparing their own versions of the Arizona initiative (Miller, 2010).

\section{Nativist Framings of Immigration}

As this brief overview of recent immigration policy indicates, nativists have largely defined the debate and agenda for immigration in the US in the last few years (Barry, 2008b; Lakoff \& Ferguson, 2006, p. 6). Nativism as used here refers to the expression and exhibition of a preference for U.S. citizens solely because they are "native" (De Genova, 2005, pp. 60-61). According to De Genova (2005), nativism is not a preoccupation with the foreignness of migrants or of internal minorities as much as it is a promotion of the priority of U.S. citizens. In this way there can be nativists of the right and of the left, with the latter often adopting racial justice positions favouring native minorities (p. 61). Indeed, racist attitudes and expressions against immigrants may be a manifestation of nationalist practices, of the desire to maintain an "imagined privileged relation" between an equally imagined race, ethnicity, or culture and a particular national space (Hage, 1998, pp. 28 \& 38; Stevens, 2009). In this way, "pro-immigrant” expressions of tolerance for ethnic or racial "diversity," as in official discourses of multiculturalism, can also constitute racialized ways of managing national space by those who see themselves as its rightful inhabitants (Hage, 1998).

Nativists have framed the debate in the US through a combination of website appeals by lobby groups (Numbers USA), ${ }^{12}$ popular radio talk shows (e.g., Rush Limbaugh), and television "news" (Lou Dobbs on CNN; Fox News). Nativists' domination of local media outlets and their ability to organize at the grassroots have shifted the national debate in an increasingly conservative direction. Republicans and Democrats who initially supported immigration reform have become more cautious or have become restrictionists themselves, as in the case of Republican Senator John McCain, a former co-sponsor of a comprehensive immigration reform bill with Democratic Senator Edward Kennedy (Goldman, 2010). Those who were earlier marginalized as extreme have moved to the mainstream, as former U.S. Republican Representative Tom Tancredo's case shows (Anti-Defamation League, 2007). Reflecting this rightward shift, the tenor of the 2007-08 presidential primary campaign debates was conservative on immigration. Even when Democrats (and Obama) talked about the legalization of 12 million undocumented immigrants, they were careful to avoid the term "amnesty," stressed the need to "get in line," and affirmed their strong support for "securing our borders" as a first step.

What made the nativists' voice on the immigration issue so powerful, especially in the face of similar resolve on the part of immigrants and immigrant rights advocates, 
as shown in the 2006 immigrant rights marches (Bada, Fox, \& Selee 2006)? Immigration restrictionists drew upon a combination of economic, security, and legal arguments to stir anxiety and build on insecurities in sectors of the population (Lakoff \& Ferguson, 2006; De Genova, 2005). Economic arguments are not new and have long been tied to concerns over the impact of trade and the restructuring of industry and work in the US. Many economic arguments also reflect a class division between those who see their work or wages affected by the presence of immigrants and those who see advantages to employers and consumers because of the ability to rely on cheap labour. Even though the latest wave of nativism began during a period of relative economic prosperity, the recent economic crisis and unemployment in the US have lent even more force to these arguments. For example, two of the largest immigration-restrictionist groups, Federation for American Immigration Reform (FAIR) and Numbers USA, have positioned themselves on the side of "citizen workers" during the economic crisis, arguing that high immigration undermines American workers (Barry, 2008b).

Although security issues have long been entangled with immigration debates, in the first decade of the $21^{\text {st }}$ century security discourse came to occupy an especially important place in these debates. In the post-9/ll environment, nativists and others seized upon border security as a symbol of the government's failure to protect the nation. Politicians used security arguments to rationalize both the buildup of national border security and the extension of immigration enforcement throughout the country (Koulish, 2010). This concern with national security overlapped with a growing insecurity about the changes wrought by immigration, especially in "new destination" areas of the country, such as southern states that had previously seen little immigration from Mexico and Central America (Zúñiga \& Hernández-León, 2005). This insecurity was expressed as a problem of costs to communities (in the form of taxes, use of education and health services, and overcrowded housing), but it was also seen as a cultural threat. The presence of ethnically different people in communities that had long been black and/or white; the encroachment of Spanish in stores, signs, radio and television; and the fear that "assimilation" was unlikely to occur all contributed to this sense of threat (Chavez, 2008; Huntington, 2004). In this way, national security became the means by which to legitimize concerns about cultural threat that might otherwise invite accusations of racism.

Focusing on illegality played a similar legitimating role. "What part of illegal don't you understand?” and "Illegal is illegal, period!” were popular retorts to any discussion of immigration reform or of humane treatment for unauthorized immigrants. As Lakoff and Ferguson (2006) note, “'Illegal alien’ not only stresses criminality, but stresses otherness" (p. 4). Stressing the illegality of immigrants led to calls for punishment via their detention and deportation; denial of access to services, benefits, or assistance of any kind; and rejection of policies that would "forgive" past transgressions through legalization of status. As Nevins (2002, p. 121) points out, "the law" in the United States serves as a powerful ideological construct dividing good from evil. In this context, framing anti-immigration sentiments as opposition to illegality and support for rule of law makes such sentiments seem more legitimate.

Studies in Social Justice, Volume 4, Issue 2, 2010 


\title{
Securitization of Immigration: Framing by States
}

This discussion of framing has so far focused on the role of nativist groups in the US. But a growing literature on securitization suggests that states also engage in framings around immigration. Indeed, immigration is one area where states can reassert their national sovereignty under globalization. The state's authority and power are most clearly manifested in, and symbolized by, its border control policies. Securitizing migration leads states to adopt certain policy tools. In particular, states expand their use of "techniques of policing" applied to border security (Andreas, 2003). This can take the form of high-tech surveillance systems, increases in funding and personnel destined to border security, and related policies such as expanded detention, expedited removal, and the externalization of borders.

States also securitize migration through discursive means, by engaging in “insecurity framing” (Huysmans, 2006, p. 4). According to Huysmans (2006):

\begin{abstract}
Securitizing immigration and asylum constructs political trust, loyalty and identity through the distribution of fear and an intensification of alienation. It is a peculiar process of constitution of a political community of the established that seeks to secure unity and identity by instituting existential insecurity (emphasis mine). (p. 47)
\end{abstract}

This mobilization of fear and institution of insecurity are key components of the securitization of migration. Both are accomplished by "instituting credible claims" that migrants are a "danger, risk, or threat" to the survival of political units, and by conveying a sense of urgency or crisis (Huysmans, 2006, pp. 4 \& 47). As Hage (1998) notes, this process plays on a "trauma resulting from a fear of losing...one's anchorage in the nation" (pp. 23-24). This framing of migration also draws a boundary around the political community and privileges this community over migrants, outsiders, and foreigners in the allocation of protection and rights. Likewise, it creates distance between members of the community and those migrants, outsiders, and foreigners.

Securitizing migration therefore makes ample political sense for states in terms of symbolic political value, the assertion of national sovereignty, and the political payoff of fear, such as votes for those who advocate border security. While the material dimensions of border security-the border militarization and surveillance technology-may primarily affect non-citizens, the discursive elements can create fear and so generate acceptance of these policies among citizens.

Citizens who are immigrant advocates, however, may find themselves confronting both material and discursive dimensions of securitization head on. Border security policies, heightened surveillance, and laws that criminalize aid to migrants can make advocates the target of surveillance and prosecution and restrict the resources they need to continue their advocacy. The state's insecurity framing of migration can make it even harder for advocates to influence public opinion and to devise effective counter-framing strategies. In particular, securitization presents advocates with the difficult challenge of reframing migration out of the security discourse of the state, a task that requires advocates to effectively displace the fear and insecurity that has settled around immigration. 


\section{Advocates Fight Back? Engaging National Policy Frames}

As noted above, most immigration debates in the US in the 2000s are centered on three dominant discourses: economics, security, and law. All three begin and end with the nation as the primary reference point, and all three are employed by opponents of unauthorized migration. Migrant advocates are drawn into these dominant ways of framing migration in their efforts to correct, counter, or challenge opponents' arguments. This has the advantage of using language that is intelligible to the majority of citizens, but it also poses several fundamental disadvantages for advocates.

First, all three discourses limit one's ability to draw on universal (not national citizenship-based) frames, including human rights. Engaging with these discourses, even when positing an inclusive national frame against the exclusionary framing of nativists, weakens advocates' ability to pose more lasting and far-reaching alternatives to contemporary approaches to illegal migration, because these would require breaking with the "nationalist commonsense" (De Genova, 2005). Second, the source of power in nativist arguments lies in their ability to stir citizens' feelings of fear and insecurity (Lakoff \& Ferguson, 2006). When advocates diminish those concerns or set them aside, they are less likely to succeed in re-framing the way the public views the issues. This presents a dilemma for migrant advocates: they either talk past the majority of citizens, or else they are forced to accept the nationally bounded terms of the debates, putting them in a weaker position vis-à-vis their critics. Advocates' message needs to resonate: it needs to speak to the values, concerns, and fears of the majority without succumbing to the same terms of reference as the dominant anti-migration frames.

The difficulties of this task can be seen in the following examples. Much of the debate in the United States has focused on costs that undocumented migrants impose on public services, or on their impact on wage levels in low-skilled jobs. Migrant advocates may take on these arguments via myth-combating or truth strategies, in which they point to studies and facts that counter the claims of immigration opponents. For instance, the Mexican-American Legal Defense and Educational Fund, MALDEF, has set up a website called "Truth in Immigration," whose mission is to rebut legal and factual inaccuracies about immigrants and Latinos. ${ }^{13}$ To rebut myths with facts is an essential task. However, advocates risk getting pulled into point-by-point disputations of restrictionists' claims or “cost arguments” (Bosniak, 1997), where the relative merits of the pro-migrant position hinge on the costs "balancing out." If it then turns out that undocumented immigrants "cost" more than they "contribute," advocates are forced to abandon their main line of defence. Moreover, a disbelief of facts or "fact resistance" tends to operate in the securitized setting of immigration. Dauvergne notes (2008, pp. 99-100), "[F]act resistance is important because there is no obvious way to counter it ...”. An advocacy based on correcting the facts, she continues, "cannot be the entire strategy" (Dauvergne, 2008, p. 100).

Another difficulty is that assertions that "immigrants take American jobs" or that they lower wages often require complex economic counter-arguments. These may focus on macro-economic or industry studies that show a limited cost burden or impact on wages, or a dynamic effect on employment. Yet such studies are frequently posed against anecdotal "evidence," intuitive "folk economics," and oft- 
repeated claims in the media, which prove powerful despite their limited reliance on facts. Moreover, existing economic studies lend support to different sides of the immigration debate (Lowenstein, 2006). Indeed, immigration opponents mobilize their own reports, studies, polls, and "facts" to sustain their positions (Barry, 2008b). For example, in 2007 a report written by staffers at the conservative Heritage Foundation made headlines and was widely cited for stating that the total "tax burden" for the U.S. taxpayer of "low-skilled" immigrant households was a whopping US\$2.2 trillion over the lifetime of those households (Rector, Kim, \& Watkins, 2007).

Countering these claims often means that advocates risk coming off as elitist. They can appear to condone cheap labour and, in this way, share the pro-business or proemployer position (Barry, 2005). To be sure, many labour union advocates present a more sophisticated position that both supports working immigrants and calls for better enforcement of labour laws, including the right to join unions, to the benefit of all workers. But this is not a simple argument that lends itself to sound bites, nor is it widely understood or accepted, especially as labour rights claims face their own obstacles in gaining broader acceptance in U.S. society and politics (Compa, 2010).

One common response to the problem of appearing to side with employers has been to assert that employers should be punished for hiring undocumented immigrant workers. This position also serves to highlight the hypocrisy of U.S. policy, where employers continue to hire undocumented workers while little is done to enforce this component of U.S. immigration law. The problem with this position for immigrant advocates, however, is that once worksite enforcement is adopted more systematically (as in recent years), advocates are left with little grounds on which to claim that undocumented migrants still deserve to migrate for work, regardless of whether or not reasonable and practical legal pathways have yet been adopted. In other words, this is not a position that allows one to make a broader claim based on the rights of migrants to mobility in search of work.

Tom Barry writes incisively about the difficult position that immigrant advocates find themselves in because their support for immigrants in the labour market reads as hostile to the American worker. He urges advocates to engage the economics debate:

...[A]dvocates will need to start explaining how [a pathway to citizenship] will serve the common good. Whenever they call for reform, they must tell us how immigrants boost the economy, don't lower the net number of jobs available to citizens, and will increase their contributions to economy and society once legalized. (Barry, 2008a)

Similarly, Lakoff and Ferguson (2006) argue that a "frame not taken" by progressives in the immigration debate is to highlight the benefits of immigrants. But they are referring to a U.S. consumer lifestyle that has come to rely on low-wage labour: “Cheap labour increases 'productivity' and profits for employers, and it permits a cheap lifestyle for consumers who get low prices because of cheap labour. But these are not seen as 'problems.' They are benefits”' (Lakoff \& Ferguson, 2006, p. 6).

These two positions, both held out by analysts who are sympathetic to immigration advocates, illustrate the divergent views within this camp and signal the counterframing challenges posed by the economic arguments of immigration restrictionists. Moreover, they also highlight another shortcoming of many national-frame debates, 
which is that advocates are often compelled to show immigrants' "contributions" and "worthiness" to the national economy or society. This discourse of worth and deservedness is a long way from a universal human rights framing, which presumably would not distinguish among immigrants to determine whether some were more or less deserving of human rights.

Immigration reform proposals in the U.S. Congress are full of just such distinctions. For instance, the Development, Relief, and Education for Alien Minors Act (DREAM Act) that would provide legalization and a conditional path toward citizenship for a subset of young people, states as one of its conditions that eligible minors show "good moral character" and worthiness either through attendance at an institution of higher education or military service. Most advocates and immigrant groups support the DREAM Act and many work to ensure its passage. However, few discuss how the Act would fail to help those unauthorized youth who satisfy the threshold requirement of entering the US as minors but commit crimes or minor offenses, drop out of school, refuse to join the military, or simply go to work after graduating from high school (Batalova \& McHugh, 2010). This example highlights the problem of national frames that are built on conditions and exclusions. Immigrants' basic rights -to security, education, and work - are recognized based on national assessments of value, worthiness, and contributions, not on the basis of their condition as human beings.

Immigrant advocates are at a similar disadvantage in taking on the securitymigration nexus. In the years following September 11, 2001, it has become more difficult to dismiss security as a rationale for policies aimed at hardening and thickening borders or at monitoring and restricting movement of non-citizens (Fernandes, 2007; Nguyen, 2005). There is broad acceptance of the idea that "border security" is a useful way to monitor terrorist threats, even as scepticism about the effectiveness of a border fence is also widespread. This concern with security permits advocates to argue in favour of legalization programs for the undocumented that would provide security checks and move people "out of the shadows." What is striking, however, is how unpersuasive those arguments have been in the national public debate and in the recent immigration reform discussions in Congress.

This is due in large part to a third powerful way of framing the undocumented immigration issue in the US, which is to focus on its illegality. Proposals to legalize undocumented immigrants are often met with the argument that legalization rewards illegal behaviour and will only beget more illegal activity by encouraging unauthorized migration. Advocates who wish to respond to this point must diminish, if not dismiss, the importance of the illegality claim. For instance, advocates can point out that unauthorized border crossing is a misdemeanour and that unlawful presence is a civil violation (Garcia, 2006). In other words, these are not the serious crimes that restrictionists claim are perpetuated by migrants. Alternatively, advocates can highlight the hypocrisy of the immigration policy, pointing to the lack of enforcement on the demand side, as noted above. Or they can stress the contingency of the law and especially, of borders, and discuss how U.S. policies themselves have “manufactured illegality” (De Genova, 2005; Nevins, 2002). But these are complex and difficult arguments, hard to make and harder to diffuse as a popular message.

Appealing to pragmatism while conceding the unlawful means of entry or overstay of immigrants-addressing the "reality" of 12 million undocumented people in our midst-has also failed so far in the US. This appeal comes off as a cynical and 
morally inferior argument against the "principled" stance of restrictionists pushing the legality claim. Even proponents of an immigration reform that includes legalization qualify this process in conditional and cautionary terms. They seldom raise the point that legal immigration is not an option for most poor workers who wish to come to the US to work. Rather, proposals have called for immigrants to undergo "criminal background checks," pay a "fine," and "get at the end of the line" behind all of those who have applied legally and are waiting "patiently" (indeed, many for over a decade) to get their green cards. This conditionality only reinforces opponents' illegality frame.

Another difficulty is that advocates may also find themselves divided on many of the claims they advance. For example, groups that have long been critical of free trade because of the presumed loss of jobs for "American workers" may find it especially difficult to make economic arguments in support of immigrant workers (and especially, undocumented workers) taking up employment in the US. This is one reason why so much is made of the idea that immigrants take work that no Americans want to do, or why "safeguards" are often built into foreign worker hiring programs (as in the H-2A visa program) to ensure that American workers are given the chance to apply first. ${ }^{14}$ As Nicholas De Genova (2005) points out:

In spite of the fact that capitalism has been a thoroughly global affair since its inception and although there is effectively only one world economy, liberal nativist arguments consistently, stubbornly assess the case within a narrowly nationalist conceptual framework premised upon the coherence of a self-contained "national economy.” (p. 74)

Another potent if debatable position holds that immigrant workers have affected the job opportunities and lowered the wages of working-class African Americans, a claim supported by some economic studies (De Genova, 2005; Lakoff \& Ferguson, 2006). Although other economists have disputed these studies, the issue remains a difficult one for immigrant advocates to address head on. This is because of the risk of appearing to dismiss what is a historically sensitive and racially charged theme in the US (Pulido, 2007), but also because many "left nativists" share the thesis that migrants displace African Americans in the labour market and that this issue should command priority (De Genova, 2005, pp. 74 \& 77).

Divisions among advocates occur not only in the arena of economic arguments but in debates over legality as well. One reason why the New Sanctuary movement ${ }^{15}$ has seen limited support on the Left is because many people are ambivalent about protecting someone who has broken the law through illegal entry and unlawful presence. An article in The Nation reflected this ambivalence toward supporting sanctuary for "economic migrants" as opposed to political refugees (Abramsky, 2008). Similarly, faith-based communities are divided on what to do about the undocumented. Whereas many see a moral imperative in criticizing U.S. policy and in helping the undocumented, others point to biblical passages signalling the importance of obeying the "laws of man" on earth and condemn actions that circumvent or ignore these laws (Bobo, 2007).

In sum, advocates may counter restrictionists' assertions, but these counter-claims often force them onto slippery terrain. Advocates may be drawn into point-by-point disputations of restrictionist claims or "cost arguments", or they may try to diminish 
or dismiss issues that are emotionally resonant and therefore powerful, such as notions of legality, security, as well as cultural and economic threat.

\section{Conclusion}

I have argued here that given the global occurrence of migration and its links to globalization, it makes sense for migrant advocates to base their campaigns and actions on a "global frame": human rights and international law and standards applied to migrants. Yet because national legislation, national judicial systems, and national sovereignty still play a central role in determining immigration policy, international human rights law is a limited instrument for use in seeking rights for unauthorized migrants. In most restrictive immigration policy environments, moreover, arguments about economics, security, and law articulated within a national framework tend to prevail. Advocates employing a global frame may find themselves talking past the mass publics they want to influence and unable to counter their opponents effectively. Yet the advocates' dilemma is that those who tackle these arguments head on may find themselves trapped within a national paradigm and unable to lay the discursive groundwork for a significant shift in the way the public views unauthorized migrants.

How have advocacy groups handled this dilemma? In the United States international human rights as a basis for policy-making has had little resonance either among policymakers or the public. Advocates have mostly tried to argue within nationally bounded frames to pursue rights claims and to address restrictive arguments about migration based on economics, security, and legality. However, these approaches have failed to produce the kind of mobilization and political pressure that change policy and move public opinion. More importantly, they are based upon notions of national community that rely on distinctions that invariably exclude (some) migrants and support immigration controls. In this way, these nationally based approaches fall short of what is needed to advance toward widespread acceptance of migration itself as a right.

Those writing from a securitization perspective argue that states gain from mobilizing fear and insecurity, which suggests that as long as nation-states persist, the "politics of fear" are likely to remain important in constituting the nation, hardly a hospitable scenario for immigrants (Huysmans, 2006). Yet the securitization perspective also offers insights for a strategy on advancing migrants' rights. It suggests that the main obstacle to overcome for migrant advocates is not the absence of information or poor dissemination of facts regarding immigrants' circumstances and contributions to the nation. Rather, the main challenge for advocates is to displace the sources of fear and anxiety about non-citizens.

In elaborating this strategy, countering myths with facts or truth is important. Yet advocates have mostly been unable to place these facts within a new frame or revisioning of societies that both builds on universal values and resonates with the broader public. The work of re-framing needs to pay attention to the emotional power generated by opponents' frames that stir and explain anxieties. At the same time, it must lay the groundwork for a transformative vision of migration, one that is ultimately at odds with our nationalist common sense. 


\section{Notes}

1 This is a revised version of a paper originally prepared for the Global Studies Association meetings in New York City in June 2008. I thank Tanya Basok, Jane Berger, Marya Besharov, Ileen DeVault, Gallya Lahav, Risa Lieberwitz, Verónica Martínez-Matsuda, Michele Williams, and two anonymous reviewers for their very helpful comments. Raymond Hedaya provided research assistance.

2 A notable exception is the International Convention on the Protection of the Rights of All Migrant Workers and Members of Their Families. This convention has not been ratified by any of the migrant-receiving states in the Global North, yet all major migrant-producing states have ratified it.

3 For instance, in recent years the number of worksite raids has increased in the US, including those taking place in agriculture at harvest time, and most employers' organizations have supported the passage of comprehensive immigration reform that would legalize undocumented immigrant populations in the US and facilitate legal hiring of foreign workers. The U.S. Department of Justice also recently cited foreign policy concerns in its challenge of the Arizona law, SB 1070, which has generated diplomatic tensions with Mexico and other Latin American countries (McKinley, 2010).

${ }^{4}$ These include the International Covenant on Civil and Political Rights (ICCPR); the International Covenant on Economic, Social, and Cultural Rights; the Universal Declaration of Human Rights; the 1951 Refugee Convention; the United Nations International Convention on the Elimination of All Forms of Racial Discrimination and the International Convention on the Protection of the Rights of All Migrant Workers and Members of Their Families; and the International Labour Organization's Convention Concerning Migrations in Abusive Conditions and the Promotion of Equality of Opportunity and Treatment of Migrant Workers (ILO No. 143).

5 This constraint is posed by the plenary power doctrine in the United States, which holds that the executive and legislative branches of government have broad powers to regulate immigration and make policy free from judicial review.

6 The United States ratified the ICCPR in 1992.

${ }^{7}$ The organizations are the American Civil Liberties Union (ACLU), American Friends Service Committee (AFSC), National Network for Immigrant and Refugee Rights (NNIRR), National Immigration Law Center (NILC), Coalition for Humane Immigrant Rights of Los Angeles (CHIRLA), Mexican American Legal Defense and Education Fund (MALDEF), National Council of La Raza, and Detention Watch Network.

8 One case, the Detention Watch Network, makes explicit mention of the Universal Declaration of Human Rights.

9 In contrast, the two major immigration-restrictionist organizations, the Federation for American Immigration Reform (FAIR) and the Center for Immigration Studies (CIS), make no mention of rights but do stress that immigration policies should serve the "national interest."

${ }^{10}$ The National Fugitive Operations Budget increased 23-fold between FY 2003 and FY 2008, from \$9 million to \$218 million (Mendelson, Strom, \& Wishnie, 2009, p. 1).

${ }^{11}$ The U.S. Department of Justice filed a lawsuit asking for an injunction against these laws on the grounds that they were unconstitutional. In July, 2010, a judge granted a partial injunction; the Arizona Governor appealed and at this writing the case awaits a decision from the $9^{\text {th }}$ U.S. Circuit Court of Appeals.

${ }^{12}$ Numbers USA was founded in 1997 and boasts a membership of 450,000. It led an effective grassroots opposition to a proposed bill for comprehensive immigration reform in mid-2007 (Barry, 2008b).

${ }^{13}$ See http://maldef.org/truthinimmigration/.

${ }^{14}$ The H-2A program permits U.S. employers to bring temporary foreign workers into the United States for seasonal agricultural work. Employers must certify that U.S. workers are not available to perform the work before they may hire a temporary foreign worker under this program. See http://www.dhs.gov/xnews/releases/pr_1202308216365.shtm.

15 The New Sanctuary Movement is a network of faith communities around the United States that emerged in 2007 to protect immigrants and their families from unjust deportations and to change the public debate around immigration. See http://www.newsanctuarymovement.org/index.html. 


\section{References}

Abramsky, S. (2008, February 25). Gimme shelter. The Nation, 286(7), 24-28.

Andreas, P. (2003). Redrawing the line: Borders and security in the twenty-first century. International Security, 28(2), 78-111.

Andreas, P. (2009). Border games: Policing the U.S.-Mexico divide (2 ${ }^{\text {nd }}$ Ed.) Ithaca, NY: Cornell University Press.

Anti-Defamation League. (2007). Immigrants targeted: Extreme rhetoric moves into the mainstream. Retrieved from http://www.adl.org/civil_rights/anti_immigrant/rhetoric.asp

Archibold, R. C. (2010a, April 23). Arizona enacts stringent law on immigration. The New York Times. Retrieved from http://www.nytimes.com/2010/04/24/us/politics/24immig.html?th\&emc=th

Archibold, Randal C. (2010b, May 25). Obama to send up to 1,200 troops to border. The New York Times. Retrieved from http://www.nytimes.com/2010/05/26/us/26border.html?ref=todayspaper

Bada, X., Fox, J., \& Selee, A. (Eds.). (2006) Invisible no more: Mexican migrant civic participation in the United States. Washington, DC: Mexico Institute, Woodrow Wilson International Center for Scholars. Retrieved from http://www.wilsoncenter.org/topics/pubs/Invisible\%20No\%20More.pdf

Barry, T. (2005, August 9). The immigration debate: Politics of class and corporations. Retrieved from www.americaspolicy.org

Barry, T. (2008a, November 18). Identity politics and the Latino payback on immigration. Retrieved from http:// www.americas.irc-online.org

Barry, T. (2008b). Anti-immigration forces ready to challenge Obama. Retrieved from www.americas.irconline.org

Basok, T. (2009). Counter-hegemonic human rights discourses and migrant rights activism in the U.S. and Canada. International Journal of Comparative Sociology, 50(2), 183-205.

Batalova, J. \& McHugh, M. (2010, July). DREAM vs. Reality: An analysis of potential DREAM Act beneficiaries. Insight. New York, NY: Migration Policy Institute.

Benford, R. D. \& Snow, D.A. (2000). Framing processes and social movements: An overview and assessment. Annual Review of Sociology 26, 611-39.

Bobo, K. (2007, May). Making it plain: E-mails offer insights and challenges. Faith Works, Newsletter of Interfaith Worker Justice, 3.

Bosniak, L. (1997). "Nativism” the concept: Some reflections. In J. F. Perea, (Ed), Immigrants out! The new nativism and the anti-immigrant impulse in the United States (pp. 279-299). New York, NY: New York University Press.

Bosniak, L. (2000). Universal citizenship and the problem of alienage. Northwestern University Law Review, 94(3), 963-982.

Bustamante, J. (2008, March). Promotion and protections of all human rights, civil, political, economic, social and cultural rights, including the right to development. Report presented to the United Nations General Assembly.

Carens, J. (1987). Aliens and citizens: The case for open borders. Review of Politics, 49(2), 251-73.

Chavez, L. R. (2008). The Latino threat: Constructing immigrants, citizens, and the nation. Stanford, CA: Stanford University Press.

Cole, D. (2006). The idea of humanity: Human rights and immigrants' rights. Columbia Human Rights Law Review, 37, 627-58.

Cole, P. (2000). Philosophies of exclusion: Liberal political theory and immigration. Edinburgh: Edinburgh University Press.

Compa, L. (2010). Framing labor's new human rights movement. In R. Kolins Givan, K. M. Roberts, \& S. A. Soule, (Eds.), The diffusion of social movements: Actors, mechanisms, and political effects (pp.5677). New York, NY: Cambridge University Press.

Cornelius, W. A. \& Lewis, J. M. (Eds.). (2007). Impacts of border enforcement on Mexican migration: The view from sending communities. La Jolla, CA: Center for Comparative Immigration Studies, UCSD.

Dauvergne, C. (2005). Humanitarianism, identity, and nation: Migration laws in Canada and Australia. Vancouver, BC: University of British Columbia Press.

Dauvergne, C. (2008). Making people illegal: What globalization means for migration and law. New York, NY: Cambridge University Press.

De Genova, N. (2005). Working the boundaries: Race, space, and "illegality" in Mexican Chicago. Durham: Duke University Press. 
Detention Watch Network. (2010). About the U.S. detention and deportation system. Retrieved from http://www.detentionwatchnetwork.org/aboutdetention

Doherty, C. (2007, April 12). The immigration divide. Retrieved from http://pewresearch.org/pubs/450/immigration-wedge-issue

Elias, J. (2008). Struggles over the rights of foreign domestic workers in Malaysia: The possibilities and limitations of "rights talk." Economy and Society, 37(2), 282-303.

Fernandes, D. (2007). Targeted: Homeland security and the business of immigration. New York, NY: Seven Stories Press.

Freeman, G. P. (1995). Modes of immigration politics in liberal democratic states. International Migration Review, 29(4), 881-913.

Fujiwara, L. H. (2005). Immigrant rights are human rights: The reframing of immigrant entitlement and welfare. Social Problems, 52(1), 79-101.

Garcia, M. J. (2006). Criminalizing unlawful presence: Selected issues. CRS Report for Congress. Washington, DC: Congressional Research Service, Library of Congress.

Goldman, R. (2010, May 11). John McCain border shift: “Complete danged fence.” ABC News. Retrieved from http://abcnews.go.com/Politics/john-mccain-immigration-reversal-complete-danged-fence/story?id $=10616090$

Grugel, J., \& Piper, N. (2007). Critical perspectives on global governance: Rights and regulation in governing regimes. London and New York: Routledge.

Guiraudon, V., \& Lahav, G. (2000). A reappraisal of the state sovereignty debate: The case of migration control. Comparative Political Studies, 33(163).

Hage, G. (1998). White nation: Fantasies of white supremacy in a multicultural society Annandale, Australia: Pluto Press.

Hollifield, J. F. (2004). The emerging migration state. The International Migration Review, 38(3), 885912.

Hsu, S. S., \& Aizenman, N. C. (2010, March 8). DHS corrects report that overstated ICE deportations under Obama. The Washington Post. Retrieved from http://voices.washingtonpost.com/44/2010/03/dhs-corrects-report-that-overs.html

Huntington, S. P. (2004). Who are we? The challenges to America's national identity. New York, NY: Simon and Schuster.

Huysmans, J. (2006). The politics of insecurity: Fear, migration and asylum in the EU. London, UK: Routledge.

International Labour Organization. (2002). Migrant workers, labour education, 4(129). Retrieved from www.ilo.org/public/english/dialogue/actrav/publ/129/129.pdf

Koulish, R. (2010). Immigration and American democracy: Subverting the rule of law. New York, NY: Routledge.

Lakoff, G., \& Ferguson, S. (2006). The framing of immigration. Retrieved from www.rockridgeinstitute.org/research/rockridge/immigration

Lakoff, G., \& Hazen, D., \& Dean, H. (2004). Don't think of an elephant! Know your values and frame the debate. White River Jct., VT: Chelsea Green Publishing.

Lowenstein, R. (2006, July 9). The immigration equation. The New York Times Magazine, 36-43 \& 69-71.

Lyon, B. (2008). From sanctuary to shaping international law: How unauthorized immigrant workers in America are advocating beyond U.S. borders. In C. Soohoo, C. Albisa, \& M. F. Davis, (Eds.), Bringing human rights home Vol. 3: Portraits of the movement (pp. 25-52). Westport, CT: Praeger.

McKinley, J. C. (2010, July 22). U.S. lays out case against Arizona law. The New York Times. Retrieved from http://www.nytimes.com/2010/07/23/us/23arizona.html?_r=2\&ref=immigration-and-emigration

Mendelson, M., Strom, S. \& Wishnie, M. (2009). Collateral damage: An examination of ICE's fugitive operations program. Washington, DC: Migration Policy Institute.

Merry, S. E. (2003). Rights talk and the experience of law: Implementing women's human rights to protection from violence, Human Rights Quarterly, 25(2), 343-381.

Miller, J. (2010, June 25). Twenty other states considering copying Arizona immigration law. The Huffington Post. Retrieved from http://www.huffingtonpost.com/2010/06/25/twenty-other-statesconsi_n_626095.html

Money, J. (1999). Fences and neighbors: The political geography of immigration control. Ithaca, NY: Cornell University Press.

Moser, B. (2006, August 28). White heat: What's fueling the new nativism? The Nation. Retrieved from http://www.thenation.com/doc/20060828/moser

Nevins, J. (2002). Operation Gatekeeper: The rise of the "illegal alien" and the making of the U.S.Mexico boundary. New York, NY: Routledge. 


\section{Maria Lorena Cook}

Nevins, J. (2008). Dying to live: A story of U.S. immigration in an age of global apartheid. San Francisco, CA: Open Media/ City Lights Books.

Ngai, M. M. (2006). Impossible subjects: Illegal aliens and the making of modern America. Princeton, NJ: Princeton University Press.

Nguyen, T. (2005). We are all suspects now: Untold stories from immigrant communities after 9/11. Boston, MA: Beacon Press.

Park, T. (2008, November 7) U.S. deporting record levels of undocumented immigrants: ICE. Jurist: Legal News and Research. Retrieved from http://jurist.law.pitt.edu/paperchase/2008/11/us-deportingrecord-levels-of.php

Pew Research Center for the People and the Press. (2010, May 12). Public supports Arizona immigration law. Retrieved from http://pewresearch.org/pubs/1591/public-support-arizona-immigration-law-poll.

Preston, J. (2009, August 3). Firm stance on illegal immigrants remains policy. The New York Times. Retrieved from http://www.nytimes.com/2009/08/04/us/politics/04immig.html?_r=1\&hp

Pulido, L. (2007). A day without immigrants: The racial and class politics of immigrant exclusion. Antipode, 39(1) 1-7.

Rector, R., Kim, C., \& Watkins, S. (2007). The fiscal cost of low-skill households to the U.S. taxpayer. Retrieved from www.heritage.org/research/welfare/sr12.cfm

Sassen, S. (1999). Guests and aliens. New York, NY: The New Press.

Schwenken, H. (2005). “Domestic Slavery” versus “Workers' Rights”: Political Mobilizations of Migrant Domestic Workers in the European Union, (Working paper 116). Center for Comparative Immigration Studies, University of California, San Diego.

Sharma, N. (2006). Home economics: Nationalism and the making of "migrant workers" in Canada. Toronto: University of Toronto Press.

Snow, D. A., \& Benford, R.B. (1992). Master frames and cycles of protest. In A. D. Morris \& C. McClurg Mueller (Eds.), Frontiers in social movement theory. New Haven, CT: Yale University Press.

Statham, P., \& Mynott, E. 2002. "The Dilemma of Anti-Racist and Pro-Migrant Mobilisation in Britain: Visibility or Political Power?” Paper for the Joint Sessions of the ECPR 'Immigration Politics: Between Centre and Periphery, National States and the EU,” Turin, Italy, 22-27 March.

Stevens, J. (2009). States without nations: Citizenship for mortals. New York, NY: Columbia University Press.

Soysal, Y. N. (1994). Limits of citizenship: Migrants and postnational membership in Europe. Chicago, IL: University of Chicago Press.

Tarrow, S. (1998). Power in movement: Social movements and contentious politics ( $2^{\text {nd }}$ ed.). Cambridge, UK: Cambridge University Press.

U.S. GAO, United States Government Accountability Office (GAO). (2006). Illegal immigration: Bordercrossing deaths have doubled since 1995; border patrol's efforts to prevent deaths have not been fully evaluated. GAO-06-770 (August). Washington, DC: GAO.

U.S. GAO, United States Government Accountability Office (GAO). (2009). Secure border initiative: technology deployment delays persist and the impact of border fencing has not been assessed. GAO09-896 (September). Washington, DC: GAO.

Walzer, M. (1983). Spheres of justice: A defense of pluralism and equality. New York, NY: Basic Books.

Yau, J. (2005, March 1). Promise and prospects of UN's Convention on Migrant Workers. Retrieved from http://www.migrationinformation.org/Feature/display.cfm?id=288

Zúñiga, V., \& Hernández-León, R. (Eds.). (2005). New destinations: Mexican immigration in the United States. New York, NY: Russell Sage Foundation. 